\title{
Afstemming in de eenentwintigste eeuw: de rol van bewijsvermoedens voor onderling afgestemde feitelijke gedraging door deelname aan online platforms
}

\author{
Prof. mr. A. Gerbrandy en T. Binder*
}

In de zaak Eturas werd het Hof van Justitie gevraagd om een nadere uitleg te geven aan het begrip 'afstemming tussen ondernemingen' in de zin van een onderling afgestemde feitelijke gedraging (art. 101 lid 1 VWEU). Het belang van dit arrest ligt ten eerste in de constatering dat afstemming plaats kan vinden door middel van deelname van ondernemingen aan een online platform beheerd door een derde (niet-concurrerende) partij, en ten tweede in de verdere verfijning van de toelaatbaarheid van bewijsvermoedens; meer specifiek van de grenzen die het onschuldbeginsel daaraan stelt.

Hvf 21 januari 2016, zaak C-74/14, Eturas UAB e.a.I Lietuvos Respublikos konkurencijos taryba, ECLI:EU:C: 2016:42.

\section{Aanleiding voor de prejudiciële vragen}

Het hier te bespreken arrest volgt op het verzoek om een prejudiciële beslissing van de hoogste bestuursrechter van Litouwen. ${ }^{1}$ De vragen werden gesteld in een geding tussen Eturas UAB en een aantal reisbureaus enerzijds, en de mededingingsautoriteit van de Republiek Litouwen anderzijds. ${ }^{2}$

De vennootschap Eturas UAB is eigenaar en beheerder van E-TURAS, een gemeenschappelijk onlinesysteem

* Prof. mr. A. (Anna) Gerbrandy is hoogleraar mededingingsrecht aan de Universiteit Utrecht. T. (Tom) Binder is student in de master European Law aan de Universiteit Utrecht en als student-assistent verbonden aan het Europa Instituut van die universiteit.

1. Lietuvos vyriausiasis administracinis teismas, hierna: 'de verwijzende rechter'.

2. Lietuvos Respublikos konkurencijos taryba, hierna: 'de mededingingsautoriteit'. voor reisboekingen. Dit systeem is geintegreerd in de afzonderlijke websites van verschillende reisbureaus in Litouwen, en biedt hun daarmee de mogelijkheid om volgens een door Eturas UAB bepaalde uniforme wijze van boeking reizen te koop aan te bieden. ${ }^{3}$ Zo stelt E-TURAS de reisbureaus onder meer in staat een internetkorting toe te passen op de reizen die via het onlinesysteem worden geboekt.

Het is voor de mededingingsautoriteit komen vast te staan dat de directeur van Eturas UAB, met betrekking tot deze internetkorting op 25 augustus 2009 een e-mailbericht heeft verzonden naar verschillende reisbureaus. In deze e-mail, met als titel 'Stemming', werd de reisbureaus verzocht zich uit te spreken over de wenselijkheid om de internetkorting te verlagen van $4 \%$ naar 1 à $3 \%$. $^{4}$ De beheerder van E-TURAS verzond vervolgens op 27 augustus 2009 via het interne mailsysteem een mededeling met als titel 'Mededeling over de verlaging van de korting op reisboekingen via internet naar 0 à $3 \%$ '. Deze mededeling bevatte de volgende informatie:

'[g]elet op de verklaringen, voorstellen en wensen van de reisbureaus met betrekking tot de toepassing van een kortingspercentage voor reisboekingen via internet, wordt de mogelijkheid ingevoerd om internetkortingen te verlenen van, naar keuze, 0 à $3 \%$. (...) Opgelet! Bij reisbureaus die kortingen van meer dan $3 \%$ verlenen, wordt het kortingspercentage om 14 uur automatisch verlaagd naar 3\%. ${ }^{5}$

De mededingingsautoriteit stelde vast dat de betrokken reisbureaus weliswaar niet verhinderd werden hun klanten extra kortingen van meer dan 3\% te verlenen, maar 
dat zij dergelijke kortingen enkel konden verlenen indien zij extra technische formaliteiten vervulden. ${ }^{6}$

Op basis van deze e-mails concludeerde de mededingingsautoriteit dat Eturas $\mathrm{UAB}$ en de betrokken reisbureaus inbreuk maakten op artikel 101 lid $1 \mathrm{VWEU}$; aan hen werden geldboetes opgelegd. ${ }^{7}$ Het besluit van de mededingingsautoriteit werd angevochten. Voor de verwijzende rechter hebben de reisbureaus betoogd dat zij niet aansprakelijk kunnen worden gesteld voor de eenzijdige handeling van Eturas UAB. Sommige van hen stelden daarbij dat zij de verzonden mededeling niet hadden ontvangen of niet hadden gelezen. ${ }^{8}$ Daartegenover stelde de mededingingsautoriteit dat het boekingssysteem de reisbureaus in staat stelde om, zelfs zonder direct contact, wilsovereenstemming te bereiken over een beperking van de kortingen, en voorts dat wie zich niet verzet tegen de beperking van de kortingen, wordt geacht er stilzwijgend mee in te stemmen. ${ }^{9}$ Daarbij achtte de mededingingsautoriteit het van belang dat de reisbureaus die in de betrokken periode van het E-TURASboekingssysteem hadden gebruikgemaakt en geen bezwaar hadden gemaakt, redelijkerwijs konden aannemen dat alle andere gebruikers van dat systeem hun kortingen eveneens tot een maximum van $3 \%$ zouden beperken. ${ }^{10}$

De verwijzende rechter stelde twee prejudiciële vragen. ${ }^{11}$ De eerste vraag luidt of artikel 101 lid 1 VWEU aldus moet worden uitgelegd dat kan worden aangenomen dat wanneer ondernemingen een gemeenschappelijk geautomatiseerd informatiesysteem gebruiken, en het bewezen is dat in dit systeem een mededeling over de beperking op het verlenen van kortingen is opgenomen en een technische beperking ten aanzien van het invoeren van een kortingspercentage is aangebracht, deze ondernemingen wisten, of hadden moeten weten, dat deze mededeling in het informatiesysteem voorkwam en dat zij, door zich niet tegen de toepassing van deze beperking op het verlenen van kortingen te verzetten, stilzwijgend met deze beperking op het verlenen van prijskortingen hebben ingestemd - en dus aansprakelijk kunnen worden gehouden voor onderling afgestemde feitelijke gedragingen. De tweede vraag luidt, indien de eerste vraag ontkennend wordt beantwoord, welke factoren in anmerking moeten worden genomen om te bepalen of de ondernemingen die een gemeenschappelijk geautomatiseerd informatiesysteem gebruiken hun gedragingen onderling hebben afgestemd in de zin van artikel 101 lid 1 VWEU.

\section{Arrest van het Hof van Justitie}

Met deze vragen, die samen worden onderzocht, wenst de verwijzende rechter volgens het Hof van Justitie in wezen te vernemen of artikel 101 lid 1 VWEU aldus moet worden uitgelegd dat de reisbureaus kunnen worden vermoed te hebben kennisgenomen of noodzakelijkerwijs te moeten hebben kennisgenomen van de mededeling en, indien zij zich niet hebben verzet tegen die praktijk, te hebben deelgenomen aan een onderling afgestemde feitelijke gedraging in de zin van die bepaling. ${ }^{12}$ In de eerste plaats buigt het Hof van Justitie zich over de vraag wanneer mag worden angenomen dat de betrokken ondernemingen wetenschap hebben gehad van een tot mededingingsverstoring aanleiding gevende mededeling. $\mathrm{Na}$ het recapituleren van vaste rechtspraak overweegt het Hof van Justitie allereerst dat het antwoord op de vraag of de loutere verzending van een mededeling afdoende kan bewijzen dat de ontvangers van de inhoud van die mededeling op de hoogte waren of noodzakelijkerwijs moesten zijn, niet voortvloeit uit het begrip 'onderling afgestemde feitelijke gedraging' en daar evenmin intrinsiek mee is verbonden. Omdat een dergelijke afweging moet worden geacht betrekking te hebben op de beoordeling van de bewijzen en de bewijsstandaard, is zij krachtens het beginsel van procedurele autonomie, behoudens de beginselen van gelijkwaardigheid en doeltreffendheid, een zaak van het nationale recht. ${ }^{13}$

Het Hof van Justitie overweegt vervolgens dat het doeltreffendheidsbeginsel vereist dat het bewijs van een schending van het mededingingsrecht van de Unie niet alleen door middel van rechtstreekse bewijzen kan worden geleverd, maar ook door middel van objectieve en onderling overeenstemmende anwijzingen, ${ }^{14}$ omdat nationale voorschriften inzake de beoordeling van de bewijzen en de bewijsstandaard de toepassing van de Unierechtelijke mededingingsregels niet onmogelijk of overdreven moeilijk mogen maken. ${ }^{15}$ Daarna overweegt het Hof van Justitie dat het vermoeden van onschuld - een algemeen beginsel van Unierecht thans neergelegd in artikel 48 lid 1 van het Handvest dat dientengevolge door de lidstaten moet worden geëerbiedigd wanneer zij het mededingingsrecht van de Unie ten uitvoer brengen - zich ertegen verzet dat de verwijzende rechter uit de loutere verzending van het e-mailbericht (de 'in het hoofdgeding aan de orde zijnde mededeling') afleidt dat de betrokken reisbureaus noodzakelijkerwijs op de hoogte moesten zijn van de inhoud van die mededeling. ${ }^{16}$ Het vermoeden van onschuld verzet zich er echter niet tegen dat de verwijzende rechter oordeelt dat de verzending van die mededeling, gelet op andere objectieve en onderling overeenstemmende aanwijzingen, het vermoeden kan schragen dat de in het hoofdge-

12. Eturas, punt 26
13. Eturas, punt 34
14. Eturas, punt 37
15. Eturas, punt 35
16. Eturas, punt 39

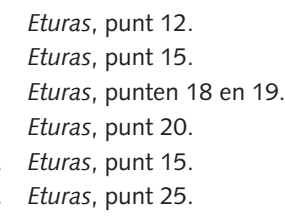


ding aan de orde zijnde reisbureaus vanaf de datum van verzending van die mededeling op de hoogte waren van de inhoud van die mededeling, mits de reisbureaus de mogelijkheid behouden om dat vermoeden te weerleggen. ${ }^{17}$ Voor die weerlegging mag de verwijzende rechter geen buitengewone of onrealistische stappen opleggen. ${ }^{18}$ In de tweede plaats, met betrekking tot het vermoeden van deelname aan een onderling afgestemde feitelijke gedraging, brengt het Hof van Justitie de drie bestanddelen van dit element van artikel 101 lid 1 VWEU in herinnering: 'behalve de afstemming tussen de betrokken ondernemingen, [wordt] een daaropvolgend marktgedrag en een causaal verband tussen beiden vereist' ${ }^{19}$ Het Hof van Justitie oordeelt dat, in de onderhavige zaak, kan worden geconcludeerd dat er sprake is van afstemming tussen de reisbureaus die op de hoogte waren van de inhoud van de in het hoofdgeding an de orde zijnde mededeling. Die reisbureaus worden geacht stilzwijgend te hebben ingestemd met een gemeenschappelijke mededingingsverstorende praktijk, aangezien ook de andere twee bestanddelen van een onderling afgestemde feitelijke gedraging, te weten het daaropvolgend marktgedrag en een causaal verband tussen beide, aanwezig zijn. ${ }^{20}$ Afhankelijk van de beoordeling van de bewijzen door de verwijzende rechter kan een reisbureau worden vermoed aan die afstemming te hebben deelgenomen vanaf het moment dat het op de hoogte was van de inhoud van de in het hoofgeding aan de orde zijnde mededeling.

Het Hof van Justitie overweegt dat indien niet kan worden aangetoond dat een reisbureau op de hoogte was van die mededeling, zijn deelname aan de afstemming niet kan worden afgeleid uit het loutere bestaan van de technische beperking die is aangebracht in het boekingssysteem, zonder dat op grond van andere objectieve en onderling overeenstemmende aanwijzingen vaststaat dat het stilzwijgend heeft ingestemd met een mededingingsverstorende handeling. ${ }^{21}$

In de derde plaats noemt het Hof van Justitie een aantal manieren waarop de betrokken ondernemingen het vermoeden van deelname aan de onderling afgestemde feitelijke gedraging zouden kunnen weerleggen. Allereerst kan een reisbureau het vermoeden weerleggen door aan te tonen dat het zich publiekelijk heeft gedistantieerd van de gedraging, of doordat het die gedraging bij de administratieve entiteiten heeft aangegeven. ${ }^{22}$ Uit het arrest blijkt dat deze opsomming van manieren niet limitatief is, daar het Hof van Justitie overweegt dat de betrokken reisbureaus het vermoeden bijvoorbeeld tevens hadden kunnen weerleggen door duidelijk en uitdrukkelijk bezwaar te maken bij de beheerder van E-TURAS. ${ }^{23}$ Ook kan het vermoeden van deelname worden weerlegd door middel van andere bewijzen. Zo

17. Eturas, punt 40.
18.
19. Eturas, punt 41.
20.
21. Eturas, punt 42.
22.
23.
23. overweegt het Hof van Justitie dat dit kan door het vermoeden van causaal verband tussen de afstemming en het marktgedrag te weerleggen, bijvoorbeeld door te bewijzen dat systematisch een korting is toegepast die de betrokken bovengrens overschrijdt. ${ }^{24}$

\section{Commentaar}

Het hier besproken arrest kan vanuit verschillende perspectieven worden bezien. Wij belichten er twee: de rol van technologie en de wijze waarop technologie kan worden gebruikt in een onderling afgestemde feitelijke gedraging en de - in algemene zin los van de technologie staande - overwegingen ten aanzien van het bewijzen van een onderling afgestemde feitelijke gedraging.

De rol van technologie

Het Hof van Justitie wijkt in het Eturas-arrest niet af van de uitleg die het in eerdere uitspraken reeds gaf aan het begrip onderling afgestemde feitelijke gedraging. Maar doordat de afstemming volledig elektronisch plaatsvond, brengt het Eturas-arrest deze interpretatie nu ook naar de eenentwintigste eeuw. Eerder, in het $T$-Mobile-arrest, bleek dat een enkele bijeenkomst onder omstandigheden al voldoende kan zijn om een dergelijke afstemming teweeg te brengen. ${ }^{25}$ In Eturas is nu vast komen te staan dat aan het bestanddeel 'afstemming tussen ondernemingen' ook kan worden voldaan zonder dat de deelnemende partijen daadwerkelijk bijeenkomen of anderszins op (in)directe wijze met elkaar in contact staan: een unilaterale mededeling verzonden door een niet-concurrerende partij via een gemeenschappelijk online boekingssysteem kan afstemming tussen die ondernemingen tot gevolg hebben. Hoewel het Hof van Justitie in het arrest hierbij eveneens naar het arrest T-Mobile verwijst, is al opgemerkt dat deze verwijzing overbodig is: $T$-Mobile gaat in zekere zin vérder omdat een enkele fysieke bijeenkomst uiteindelijk minder langdurig effect zal hebben dan een permanente wijziging in een online (kortingen)systeem. ${ }^{26}$ De wijziging in het

24. Eturas, punt 49 .

25. HvJ 4 juni 2009, zaak C-8/08, T-Mobile, ECLI:EU:C:2009:343, punt 59. Hoewel de verwijzende rechter in de T-Mobile-zaak bevraagt of het Anic-bewijsvermoeden ook geldt bij een enkele bijeenkomst stelt het Hof van Justitie in meer algemene bewoordingen dat sprake kan zijn van 'afstemming' bij een enkele bijeenkomst. Zie met betrekking tot deze uitspraak: A. Gerbrandy, 'Case C-8/08, T-Mobile Netherlands BV, KPN Mobile NV, Orange Nederland NV, Vodafone Libertel NV v. Raad van bestuur van de Nederlandse Mededingingsautoriteit, Judgment of the Court (Third Chamber) of 4 June 2009, not yet reported', Common Market Law Review 47, 2010(4), p. 1199-1220; E.M.H. Loozen, 'T-Mobile Netherlands: het Hof schenkt klare wijn over de uitleg van een doelbeperking bij een economische benadering', NTER 2009/7, p. 229-236; L. Heijnen-Bos en A. Looijenstijn-Clearie, '4 juni 2009, zaak C-8/08, T-Mobile Netherlands BV e.a./Raad van bestuur van de Nederlandse Mededingingsautoriteit (m.nt. L. Heijnen-Bos en A. LooijestijnClearie)', SEW Tijdschrift voor Europees en economisch recht, 2009, 3, p. 121-126.

26. O.a. A. Heinemann en A. Gebicka, 'Can Computers Form Cartels? About the Need for European Institutions to Revise the Concertation Doctrine in the Information Age', Journal of Competition Law and Practice 2016(7) 
online kortingensysteem is, met andere woorden, minder vluchtig dan een enkele bijeenkomst kan zijn. In een zinnige en realistische toevoeging stelt het Hof van Justitie daarbij echter wel dat de stilzwijgende deelname aan de afstemming niet kan worden afgeleid louter uit het bestaan van de (conformerend marktgedrag afdwingende) technische beperking die is aangebracht in het gemeenschappelijk platform; stilzwijgende deelname via het gedeelde platform kan alleen worden aangenomen op voorwaarde dat (al dan niet door middel van het uit de eerste prejudiciële vraag voortvloeiende vermoeden) kan worden vastgesteld dat de onderneming op de hoogte was van de betreffende mededeling.

Doordat de afstemming werd geïnitieerd door een nietconcurrerende partij staat het arrest Eturas ook in de lijn van jurisprudentie over kartelfacilitatoren waarbij (ook) de facilitator inbreuk maakt op artikel 101 WVEU. $^{27}$ Ofschoon het door de verwijzende rechter in de Eturaszaak niet nader aan de orde werd gesteld, brengt de rol van technologie voor betrokken marktdeelnemers nieuwe mededingingsrechtelijke risico's mee. ${ }^{28}$ Zo illustreert het Eturas-arrest hoe een derde, niet-concurrerende partij als beheerder van een technologisch platform, na afstemming tussen ondernemingen op unilaterale wijze te hebben geinitieerd, het kartel tot stand brengt door het met deze afstemming conformerend marktgedrag af te dwingen via het aanbrengen van een technische beperking voor de gebruikers van het online platform. Het was al duidelijk dat dit kan zonder het gebruik van een technologisch (communicatie)platform; het Eturasarrest toont echter aan dat de rol van technologie in de ondernemingspraktijk - in dit specifieke geval de rol van online platforms - een voelbare invloed kan hebben op de toepassing van het mededingingsrecht.

In het licht van nieuwe ontwikkelingen op het terrein van communicatietechnologie kan de Eturas-zaak derhalve worden gezien als nieuwe stap in de ontwikkeling van het o.a.f.g.-leerstuk: met deze uitspraak verbindt het Hof van Justitie de bestaande interpretatie van het bestanddeel 'afstemming tussen ondernemingen' met de hedendaagse technologische realiteit waarin de opkomst van gedeelde online platforms het (al dan niet indirect) bilateraal of multilateraal contact tussen concurrenten

27. Zie HvJ 22 oktober 2015, zaak C-194/14 P, AC-Treuhand, ECLI:EU:C: 2015:717. Verschil met de casus in Treuhand is dat er in Eturas sprake is van een partij die op de upstream markt actief is. In Treuhand was de facilitator een consultancy-onderneming. Zie over facilitators in het algemeen ook: L. Solek, 'Passive Participation in Anticompetitive Agreements', Journal of European Competition Law and Practice 2016(5); en over het specifieke verschil tussen de Eturas-zaak en Treuhand: Heinemann en Gebicka 2016.

28. Dit wordt beklemtoond in veel van de korte beschouwingen die aan dit arrest zijn gewijd vanuit de praktijk. Zie bijvoorbeeld de waarschuwing dat 'In practice, the Court's judgment can be interpreted as requiring commercial users of third-party online platforms to exercise a reasonable level of care regarding the possibility that the platform operator and/or other users are engaged in illegal conduct': <www. nortonrosefulbright.com/knowledge/publications/136657/eu-courtjudgement-on-eturas-uab>. overbodig heeft gemaakt. ${ }^{29}$ Op dezelfde wijze is in het mededingingsrecht de vraag al opgeworpen of afstemming door algoritmes plaats kan vinden. ${ }^{30}$ Hoewel vooralsnog de algoritmes door daadwerkelijke personen zijn opgesteld, is een dergelijke vorm van afstemming niettemin ver verwijderd van het beeld van heren die elkaar ontmoeten in de 'smoke filled rooms' uit de vorige eeuw. ${ }^{31}$

\section{Bewijsvermoedens}

Het Eturas-arrest gaat in de kern om het bewijzen van een onderling afgestemde feitelijke gedraging, en meer precies om het bewijzen van het onderdeel afstemming (naast marktgedrag en causaliteit een van de drie elementen van een o.a.f.g.). Om uiteindelijk ook in dit type zaken - waarbij de afstemming niet heeft plaatsgevonden door een enkele of een serie van daadwerkelijke ontmoetingen - tot de vaststelling te komen dat sprake is van een inbreuk op artikel 101 lid 1 VWEU kan gebruik worden gemaakt van bewijsvermoedens. In deze paragraaf gaan we eerst in algemene zin in op bewijsvermoedens in het algemeen, vervolgens op elk van de bewijsvermoedens die in Eturas aan de orde is, en ten slotte op de mogelijkheid van het 'stapelen' van vermoedens.

\section{- $\quad$ Verschillende bemijsvermoedens, effectiviteit en het} onschuldbeginsel

Bewijsvermoedens, bij gebrek aan eenduidig direct bewijs van afstemming (of overige bestanddelen van een o.a.f.g.), staan in dienst van de effectiviteit van het Europese mededingingsrecht. Het effectiviteitsbeginsel belichaamt de instrumentele functie van het recht, waarbij voorop staat dat het recht daadwerkelijk moet kunnen worden gehandhaafd. ${ }^{32}$ Tegelijkertijd wordt het gebruik van bewijsvermoedens begrensd door het onschuldbeginsel (of de onschuldpresumptie). Het onschuldbeginsel is een waarborg tegenover een al te instrumentele benadering van het recht en is een van de fundamentele beginselen van rechtsbescherming en ondertussen opgenomen in het Handvest. Het is niet voor het eerst dat het Hof ingaat op toepassing van het onschuldbeginsel in het mededingingsrecht. Zo oordeelde het Hof van Justitie al in Hüls dat het onschuldsbeginsel van toepassing is op $E U$-mededingingsrechtelijke

29. Voor een overzicht van de ontwikkelingen, zie o.a.: A. Jones en B. Sufrin, EU Competition Law: Text, Cases and Materials, Oxford: Oxford University Press 2011, p. 160-168.

30. U.S. District Court, Northern District of California 6 april 2015 (United States of America v. David Topkins), No. 15cr-00201 (plea bargain agreement): <www.justice.gov/atr/case-document/file/628891/ download>

31. J. Priluck, 'When Bots Collude', The New Yorker 25 april 2015. Zie voor een serieuze beschouwing van de mededingingsrechtelijke implicaties: A. Ezrachi en M.E. Stucke, 'Artificial Intelligence \& Collusion: When Computers Inhibit Competition', Oxford Legal Studies Research Paper 2015(18).

32. In de klassieke tegenstelling tussen de instrumentele functie van het recht en de waarborgfunctie van het recht. Zie o.a.: E.S. Lachnit, Alternative Enforcement of Competition Law, Den Haag: Eleven Publishing 2016; A.T. Ottow, De markt meester? De zoektocht naar nieuwe vormen van toezicht, Den Haag: Boom Juridische uitgevers 2009; K. Hellingman en K.J.M. Mortelmans, Economisch publiekrecht: rechtswaarborgen en rechtsinstrumenten, Deventer: Kluwer 1989. 
procedures. ${ }^{33}$ In $V E B I C$ werd vastgesteld dat het beginsel ook door de lidstaten moet worden geëerbiedigd in mededingingsrechtelijke zaken. ${ }^{34}$ In het Eturas-arrest wordt het onschuldvermoeden nu gebaseerd op het Handvest, maar het maakt ook duidelijk dat zowel aan het onschuldbeginsel als aan het effectiviteitsbeginsel - en dus aan beide functies van het recht: waarborg- en instrumentele functie - recht moet worden gedaan in elke zaak. Tegelijkertijd wordt uit dit arrest duidelijk dat, in nationale procedures althans, de balans tussen deze beide beginselen uiteindelijk door de nationale rechter wordt bepaald.

Bewijsvermoedens in het mededingingsrecht kunnen rechtstreeks voortvloeien uit bepalingen van het Europese recht, of kunnen voortvloeien uit bepalingen van nationaal recht overeenkomstig het beginsel van procedurele autonomie van de lidstaten. Terwijl het materiële Europese mededingingsrecht uniform dient te worden uitgelegd in de 28 lidstaten van de EU, is de handhaving daarvan - aangezien harmonisatie van procesrecht grotendeels ontbreekt - ingebed in de verschillende procedurele rechtssystemen van de lidstaten. ${ }^{35}$ Dat maakt het van belang te onderscheiden of een bewijsvermoeden deel uitmaakt van het (materiële) Europese recht - in dit geval: het begrip onderling afgestemde feitelijk gedraging - of daar niet toe behoort. Dat is niet altijd direct duidelijk: in T-Mobile oordeelde het Hof van Justitie dat het vermoeden van causaal verband onderdeel is van dat materiële Europese recht (het begrip onderling afgestemde feitelijke gedraging). Daardoor geldt dat bewijsvermoeden ook bij nationale toepassing van het Europese mededingingsrecht, onafhankelijk van nationale bewijsregels. ${ }^{36} \mathrm{Bij}$ een bewijsvermoeden dat niet gebaseerd is op het Europese recht gelden de nationale bewijsregels. Daaraan worden echter wel de grenzen van de Europeesrechtelijke eisen van doeltreffendheid en gelijkwaardigheid gesteld. ${ }^{37}$ In Eturas zijn verschillende bewijsvermoedens aan de orde: het bewijsvermoeden van wetenschap (van de inhoud van de mededeling die de afstemming oplevert), waarvan de beoordeling en afweging een zaak is van het nationale recht, en het bewijsvermoeden van deelname aan afstemming, hetgeen voortvloeit uit het Europese recht. Wat ons betreft is voor beide sprake van een spanning tussen doeltreffendheid en het onschuldbeginsel, hoewel het Hof van

33. Meer precies: van toepassing op EU-procedures 'betreffende inbreuken op de voor ondernemingen geldende mededingingsregels, die tot het opleggen van geldboetes of dwangsommen kunnen leiden', HvJ 8 juli 1999, zaak C-199/92 P, Hüls, ECLI:EU:C:1999:358, punt 150.

34. 'Wanneer zij het mededingingsrecht van de Unie ten uitvoer brengen', HvJ 7 december 2010, zaak C-439/08, VEBIC, ECLI:EU:C:2010:739, punt 63.

35. Zie bijvoorbeeld: J.H. Jans, S. Prechal en R.J.G.M. Widdershoven, Inleiding tot het Europees bestuursrecht, Nijmegen: Ars Aequi Libri 2011; D. Galetta, Procedural autonomy of EU member states: paradise lost? A study on the 'functionalized procedural competence' of EU member states, Berlin: Springer 2010.

36. Zie over dit punt ook Gerbrandy 2010, p. 1214-1217.

37. Jones en Sufrin 2011, p. 1185-1186; O. Essens, A. Gerbrandy en S. Lavrijssen (ed.), National Courts and the Standard of Review in Competition Law and Economic Regulation, Groningen: Europa Law Publishing 2009, p. 47-48.
Justitie het onschuldbeginsel niet expliciet van toepassing verklaart op het bewijsvermoeden dat voortvloeit uit het Europese recht.

\section{- $\quad$ Het bemijs van metenschap}

Er kan pas sprake zijn van een onderling afgestemde feitelijke gedraging als er sprake is van afstemming tussen ondernemingen. De afstemming kan expliciet zijn of stilzwijgend, maar een o.a.f.g. kan niet worden aangenomen zonder daadwerkelijke betrokkenheid bij de afstemming, in dit geval, de uitwisseling van informatie. Dat betekent in dit geval dat pas een o.a.f.g. kan worden vastgesteld indien wordt bewezen dat de reisbureaus metenschap hadden van het gewraakte, via het systeem verzonden, mailtje. De verwijzende rechter maakte een verschil tussen daadwerkelijke wetenschap ('weten dat') en het zouden moeten hebben van wetenschap ('hadden moeten weten dat') en hoewel het Hof van Justitie de begrippen enigszins door elkaar lijkt te gebruiken, lijkt ons uit de bewoordingen van het dictum van het arrest voort te vloeien dat 'hadden moeten weten' onvoldoende is: er moet sprake zijn van een daadmerkelijk weten ('op de hoogte zijn').

Als er geen direct bewijs is van het daadwerkelijk weten - bijvoorbeeld door een verklaring van de onderneming dát de mededeling is gelezen - wordt het lastig voor een mededingingsautoriteit. Hier komt een bewijsvermoeden te hulp. Dit bewijsvermoeden van wetenschap valt, zo oordeelt het Hof van Justitie, in het domein van de procedurele autonomie van de lidstaten. Het betreft daarmee een zaak van de beoordeling van de bewijzen (dat wil zeggen: de beoordeling van de bewijskracht van de bewijsmiddelen en de waardering van de bewijsmiddelen) ter voldoening aan de bewijsstandaard (die op zichzelf de vraag betreft naar de vereiste mate van zekerheid voor vaststelling van de overtreding) die ingevolge het nationale recht geldt in deze procedures. ${ }^{38}$ Maar door op de waardering van het bewijs (iets) nader in te gaan maakt het Hof van Justitie de contouren van het balanceren tussen de vereisten van doeltreffendheid en de onschuldpresumptie wel duidelijker. Aan de ene kant kan wetenschap (van de inhoud van de mededeling van het E-TURAS-systeem) niet worden afgeleid uit de enkele verzending van een mededeling; daarvoor is nader bewijs nodig. Aan de andere kant brengt de eis van doeltreffendheid vervolgens mee dat het bewijs niet alleen door middel van rechtstreekse bewijzen kan worden geleverd, maar ook door middel van indirect bewijs: via 'objectieve en onderling overeenstemmende aanwijzingen'. In lijn met eerdere jurisprudentie levert dit indirecte bewijs dan de aanvaarding op van een vermoeden ${ }^{39}$ de enkele verzending van de mededeling kan, gelet op die andere objectieve en onderling overeenstemmende

38. Zie over deze begrippen in algemene zin onder andere Y.E. Schuurmans, Bewijslastverdeling in het bestuursrecht: zorgvuldigheid en bewijsvoering bij beschikkingen, Alphen aan den Rijn: Kluwer 2005; W.D.H. Asser, Asser-serie procesrecht; deel 3 bewijs, Deventer: Kluwer 2013.

39. Zie o.a.: HvJ 17 september 2015, zaak C-634/13 P, Total Marketing Services/Commissie, ECLI:EU:C:2015:614, punt 26 en aldaar aangehaalde rechtspraak. 
aanwijzingen, een vermoeden van wetenschap schragen. Vanwege de onschuldpresumptie is dit wel een meerlegbaar vermoeden.

Met deze aanwijzingen is het aan de nationale rechter om het bewijsmateriaal te beoordelen. Dat gebeurt tegen de achtergrond van het algemene uitgangspunt in het mededingingsrecht dat het aan de mededingingsautoriteit is om de inbreuk aan te tonen: op de mededingingsautoriteit ligt de bewijslast (zo volgt ook uit art. 2 Verordening (EG) nr. 1/2003). Een bewijsvermoeden is op die hoofdregel een gerechtvaardigde afwijking: zij houdt in 'dat een bepaalde redenering automatisch wordt toegepast: op grond van ervaring, beleid, of procedurele overwegingen wordt een bepaald feit verondersteld waar te zijn'. ${ }^{40}$ Daarbij zou, menen wij, op basis van de hoofdregel van de bewijslastverdeling echter wel het uitgangspunt moeten zijn dat alleen dan sprake is van een bewijsvermoeden indien de 'objectieve en onderlinge overeenstemmende aanwijzingen' eerst door de mededingingsautoriteit naar voren zijn gebracht. ${ }^{41}$ In het arrest is niet nader angeduid welke vorm dit zou moeten krijgen: een leesbevestiging op de mededeling zou wellicht een dergelijke aanwijzing kunnen zijn. Het is vervolgens aan de partijen om het vermoeden te ontkrachten. Daartoe is tegenbewijs nodig, waaraan dan weer geen 'buitengewone of onrealistische verwachtingen' mogen worden opgelegd, aldus het Hof van Justitie. Hier geeft het Hof van Justitie wél enkele nadere aanwijzingen: zo kan het reisbureau bijvoorbeeld aantonen de mededeling nooit te hebben ontvangen of aantonen dat het betrokken veld in het ict-systeem nooit is geraadpleegd (of pas later). Bij een automatische leesbevestiging als indirect bewijsmiddel waarop het bewijsvermoeden rust, is dit als tegenbewijs nog wel voorstelbaar; voor het overige kunnen deze aanwijzingen echter ook worden opgevat als mogelijkheid tot het leveren van (direct) bewijs van afwezigheid van het daadmerkelijke 'weten dat'.

- Het bemijsvermoeden van deelname aan de afstemming

Zoals hiervoor aangegeven moet sprake zijn van wetenschap (van de inhoud van de mededeling) alvorens sprake kan zijn van afstemming. Afstemming is onderwerp van de tweede prejudiciële vraag, die door het Hof van Justitie 'in onderlinge samenhang' met de eerste wordt beantwoord. De vragen betreffen echter twee verschillende bewijsvermoedens, hoewel het Hof voortbouwt op de redenering ten aanzien van het vermoeden van wetenschap. Het vermoeden van deelname aan de afstemming maakt ons inziens echter deel uit van de bestanddelen van het (materiële) begrip onderling afgestemde feitelijke gedraging. ${ }^{42}$ Het doeltreffendheidsbe-

40. Zie: CBb 12 augustus 2010, AB 2010/342, m.nt. L.C.M. Brekhof en A.T. Ottow.

41. Dat geldt ook bij het Anic-bewijsvermoeden van causaal verband: dat wordt pas in het leven geroepen nadat is bewezen dat er sprake is van marktgedrag en afstemming.

42. HvJ 4 juni 2009, zaak C-8/08, T-Mobile, ECLI:EU:C:2009:343, punten 51 en 52. ginsel rechtvaardigt dit vermoeden in geval de onderneming kan worden geacht op de hoogte te zijn geweest van de daartoe aanleiding gevende mededeling. (Let wel: zoals hiervoor in de weergave van het arrest genoemd, als niet is komen vast te staan dat het reisbureau op de hoogte was van de inhoud van de mededeling - bijvoorbeeld doordat het eerste bewijsvermoeden is weerlegd - dan kan deelname niet worden afgeleid uit de technische beperking, tenzij er andere objectieve en samenhangende aanwijzingen zijn voor stilzwijgende instemming met de afstemming).

Ook het vermoeden van deelname aan afstemming is een weerlegbaar vermoeden. Anders dan advocaat-generaal Szpunar concludeerde, vereist het Hof van Justitie niet dat de betrokken ondernemingen hun klanten informeren wanneer zij publiekelijk afstand wensen te nemen van de mededingingsverstorende gedraging, maar draagt het drie andere opties voor weerlegging aan. ${ }^{43}$ Het vermoeden van deelname aan de afstemming kan (ten eerste) worden weerlegd doordat de reisbureaus de systeembeheerder op de hoogte hadden gesteld van hun afwijzing van de afstemming. Dit betreft niet de distantiëring naar klanten waar de A-G aan refereert, en is ook een nuance ten opzichte van de eerdere jurisprudentie waaruit naar voren komt dat een expliciet afstand nemen van afstemming naar de andere deelnemers is vereist. ${ }^{44}$ Hoewel dergelijke distantiëring moeilijk kan zijn bij een online platform (de reisbureaus weten niet wie de e-mail heeft ontvangen) levert juist dát de destabilisering van een kartel op. ${ }^{45}$ Het is twijfelachtig of die onzekerheid ook in het leven wordt geroepen bij een distantiëring aan de systeembeheerder. ${ }^{46}$ Een andere manier om het vermoeden te weerleggen is (ten tweede) dat het reisbureau de gedraging bij de 'administratieve entiteiten' heeft aangegeven. Ten slotte wordt het vermoeden weerlegd, zo overweegt het Hof van Justitie, indien een reisbureau kan aantonen stelselmatig een hogere korting te hebben gegeven dan de maxima die in de betreffende e-mail werden genoemd. Dat levert volgens het Hof van Justitie het niet kunnen aannemen van een causaal verband tussen afstemming en marktgedrag op. Dit laatste is opvallend, omdat de andere twee wijzen van het weerleggen van vermoeden van afstemming inderdaad de afstemming betreffen, maar vooral omdat het aantonen van een hogere korting niet zozeer het weerleggen van het vermoeden van deelname aan de afstemming betreft, als wel het aantonen van afwijkend marktgedrag. Zo wordt bewijs geleverd dat van (op de afstemming volgend) marktgedrag geen sprake was. Het is dus de vraag of dit inderdaad betrekking heeft op het weerleggen van het vermoeden van causaal verband. ${ }^{47}$

43. Conclusie van A-G Szpunar bij zaak C-74/14, Eturas, ECLI:EU:C: 2015:493, punt 92.

44. O.a. HvJ 8 juli 1999, zaak C-49/92 P, Anic, ECLI:EU:C:1999:356.

45. Zie D. Bailey, 'Publicly Distancing Oneself from a Cartel', World Competition 31(2), p. 177-203, 2008.

46. Zie ook H. Hobbelen, N. Lorjé en A. Guenay, 'Selected developments in the application of EU competition law to online platforms', Mediaforum 2016 (nog te verschijnen).

47. Zie ook Heinemann en Gebicka 2016 


\section{- Het stapelen van vermoedens}

Het kan lastig zijn voor een mededingingsautoriteit het bewijs van een onderling afgestemde feitelijke gedraging te leveren. Omdat het gaat om het bewijs van een overtreding die kan leiden tot (zeer) hoge boetes wordt aan dat bewijs hoge eisen gesteld: daardoor kan effectieve handhaving in het gedrang komen. Het gebruik van bewijsvermoedens maakt deze spanning zowel zichtbaar als oplosbaar. De beide bewijsvermoedens die in Eturas aan de orde zijn, en de begrenzing daarvan door de onschuldpresumptie, zijn een voorbeeld daarvan. Toch merken we op dat het in theorie mogelijk is dat mededingingsautoriteiten een onderling afgestemde feitelijke gedraging kunnen bewijzen door te beginnen met een beetje bewijs, en vervolgens met een keten van bewijsvermoedens. In Eturas kan het bewijsvermoeden van wetenschap van de inhoud van een door een derde partij beheerd systeem verzonden mededeling worden aangenomen indien er daartoe indirect bewijs is geleverd; er is bovendien in deze zaak een bewijsvermoeden van deelname aan de afstemming indien er kennisgenomen is van de inhoud van die mededeling. In meer algemene zin, in $T$-Mobile was sprake van een bewijsvermoeden van deelname aan de afstemming indien er aanwezigheid was bij een bijeenkomst waar gevoelige informatie werd gedeeld (ook al was de partij alleen 'ontvanger' en geen 'zender' van die informatie). Daarbij kan ook het Anicbewijsvermoeden een rol spelen, dat het causaal verband betreft. Dat betekent dat het Anic-bewijsvermoeden van causaal verband kan rusten op bewijs van afstemming - maar dat kan berusten op een bewijsvermoeden. Het weerleggen van de bewijsvermoedens - bijvoorbeeld bewijzen dat je je hebt gedistantieerd van de afstemming - kan lastig zijn, mede omdat de eisen die worden gesteld aan deze weerlegging soms hoog zijn. ${ }^{48}$

De (hier nadrukkelijk versimpeld weergegeven) veronderstellingen die ten grondslag lijken te liggen aan de vermoedens zijn duidelijk: als je een e-mailbericht krijgt dan ben je meestal op de hoogte van de inhoud; als je bij een bijeenkomst aanwezig bent dan heb je meestal de 'gezonden' informatie gehoord; als je die informatie hebt ontvangen dan zal je die informatie ook wel gebruiken om je marktstrategie te bepalen; vervolgens heeft dat ook daadwerkelijk invloed op je marktgedrag. Wat begint met de vaststelling dat er informatie is 'verzonden' (mondeling of via een systeem) eindigt met het vaststellen van de overtreding. ${ }^{49} \mathrm{Op}$ vergelijkbare wijze begint in een andere serie zaken - hier niet aan de orde de bewijsketen met marktgedrag en wordt deze via het vermoeden van afstemming (indien er geen plausibele

48. Zie Bailey 2008 .

49. Met betrekking tot de problematiek rond het eenzijdig aankondigen van gedrag, zie: O. Brouwer en L. Coppi, 'Eenzijdige openbaarmaking van informatie: waar ligt de grens?', M\&M 2014/6, p. 205-215. alternatieve verklaring kan worden gegeven) verder opgebouwd naar de vaststelling van een overtreding..$^{50}$

Het onschuldvermoeden is in dit geheel dan ook van groot belang: niet alleen zouden de bewijsvermoedens alleen dan in werking moeten treden indien er 'een begin' is (waarvan de invulling grotendeels aan de nationale rechter is), maar ook zijn deze bewijsvermoedens steeds weerlegbaar. De eisen die aan tegenbewijs worden gesteld mogen bovendien niet onrealistisch zijn. Zo kan bewijs van wetenschap onder meer worden weerlegd door aan te tonen dat het e-mailbericht niet geopend is; het bewijs van deelname aan afstemming kan worden weerlegd door distantiëring of aangeven bij een mededingingsautoriteit; en ook het bewijs van causaal verband kan worden weerlegd. Het is over dat laatste vermoeden dat het $\mathrm{CBb}$ in de einduitspraak na het $T$ Mobile-arrest stelt dat hoewel het bewijsvermoeden (in die zaak) onderdeel uitmaakt van het materiële Europese recht - en dus uiteindelijk niet in de procedurele autonomie valt van de lidstaten maar rechtstreeks uit het Europese recht voortvloeit - de grenzen van het onschuldbeginsel van artikel 6 lid 2 EVRM steeds gelden. Daaruit volgen enkele concrete aanwijzingen voor het geval van die zaak, maar meer in algemene zin de overweging dat van partijen niet mag worden gevergd het vermoeden te weerleggen met 'onomstotelijk' bewijs. ${ }^{51}$ Dat lijkt ons net zo goed van toepassing te moeten zijn op de in Eturas aan de orde zijnde vermoedens.

Uit de jurisprudentie van het Hof van Justitie kunnen we afleiden dat het onschuldbeginsel niet in de weg staat aan het (afzonderlijk) gebruik van deze bewijsvermoedens. Desalniettemin kunnen opstapelingen in het licht van dat beginsel - en vanuit het perspectief van de procespositie van de onderneming - terdege als problematisch beschouwd worden. De overwegingen van het $\mathrm{CBb}$ zijn des te relevanter nu het onschuldbeginsel in Eturas wel expliciet een rol speelt in de overwegingen van het Hof van Justitie ten aanzien van het vermoeden van wetenschap - dat in de procedurele autonomie valt - maar, zo blijkt althans niet uit de uitspraak, niet expliciet bij het vermoeden van deelname aan afstemming - een bewijsvermoeden dat voortvloeit uit het materiële Europese recht. Het blijft derhalve vooralsnog onduidelijk wat volgens het Hof van Justitie, buiten de overweging dat het Handvest in algemene zin van toepassing is, de rol is van het onschuldbeginsel bij deze uit het Europees recht voortvloeiende bewijsvermoedens. Het lijkt ons echter onvermijdelijk dat hetzelfde beginsel het gebruik van beide types bewijsvermoedens begrenst.

50. HvJ 20 januari 1994, gevoegde zaken C-89, 104, 114, 116, 117, en 125-129/85, Wood Pulp, ECLI:EU:C:1994:12. Waarover bijvoorbeeld: Jones en Sufrin 2011, p. 832-833. De Wood Pulp-zaak is boeiend omdat de Commissie wel degelijk over bewijs beschikte van ontmoetingen tussen de ondernemingen, maar de zaak vooral baseerde op economisch bewijs op basis van marktomstandigheden (zie hierover uitgebreid: C. Harding en J. Joshua, Regulating Cartels in Europe, Oxford: 2010, p. 160-166)

51. CBb 12 augustus 2010, ECLI:NL:CBB:2010:BN3895. Zie voor een beschouwing hiervan met name Brekhof en Ottow, $A B$ 210/342. 